analysis, Louise Bourdua fulfills her two primary goals. She shows that there is little evidence for the direct control of the decorative schemes in Franciscan churches by the mother church in Assisi and then reveals how the concerns of local friars, lay patrons, and artists are paramount-though it can be difficult, given the vagaries of documentation, to ascertain precisely how much responsibility any of these parties had for the resulting appearance of the commission. What does become clear is that, despite the constraints placed upon them by their rule, the Franciscans found creative ways to accommodate some financial dealings with patrons, benefactors, and artists and thus to operate effectively in a less than ideal world.

\title{
SHARON GREGORY
}

\section{St. Francis Xavier University}

Jill Caskey. Art Patronage in the Medieval Mediterranean. Merchant Culture in the Region of Amalfi. Cambridge: Cambridge University Press, 2004. Pp. xiv, 327, 93 ill. ISBN 0-3218-1187-2. £55.

Jill Caskey's 2004 study Art and Patronage in the Medieval Mediterranean: Merchant Culture in the Region of Amalfi examines the art and architecture of the former duchy of Amalfi during the late eleventh, twelfth, and thirteenth centuries. What may initially appear as an eclectic collection of the artistic products of artists and patrons in that region, is really a product of a "coherent yet shifting late medieval culture that was both specific to the region and indebted to various forces well beyond its boundaries" (4). Caskey examines the heterogeneity of the art and culture in this coastal region by analyzing it in terms of the people who commissioned it, namely those involved in the act of mercatantia.

This framework was borrowed from Giovanni's Boccaccio's Decameron which described the people of Amalfi as being very proficient and consequently successful in this economic enterprise. Mercatantia, however, not only refers to trade and the principles that guide it, but also "evokes the broad cultural framework of a commercial society and a variety of activities that take place within it" (5). From the act of mercatantia the author introduces the art of mercatantia where monuments can be seen as a testament to a culture shaped primarily by commerce. The influence of mercatantia can be observed in everything from the materials made available to the artists to the works themselves being guided by the "concepts and ethics derived from the practice and discourse of mercatantia" (6).

For her study Caskey examines the art and architecture associated with two generations of the Rufolo family (the historical source for Boccaccio's tale of Landolfo Rufolo of Ravello) who served in the administration of the Kingdom of Sicily. They held various positions as merchants, tax collectors, and inspectors of ships and ports, thereby ammassing a great amount of wealth that permitted them to commission "daring works" (6), especially during the 1260 s and 1270 s. What these works demonstrate is an Amalfitan taste that was wide ranging and reflected various artistic movements and ethnic diversity. This ethnic diversity derived from a Southern Italy whose inhabitants included peoples of Latin, Greek, French, 
Jewish, and Muslim origin. What is of particular interest, however, is that in the era of the Rufolo clan wealth began to be perceived differently, in the way it was accumulated, exchanged, and displayed, and this generated theological, social, and psychological discomforts. For Caskey, these tensions "are critical to the analysis of Amalfitan art" (8).

This wealth was something that affected not only a select few, but almost every inhabitant as most people were engaged in some sort of trade. Evidence of this can be found in the widespread participation in commercial ventures by most social and professional groups, and by all the faith communities in the South. In establishing the prevalence of commerce in the Amalfi region, Caskey attempts to justify her objective of portraying the art of mercatantia "as a cultural manifestation of the late eleventh, twelfth, and thirteenth centuries" (11). She begins by outlining the merchant experience of that time by way of an analysis that includes a narration of the rise and fall of the Rufolo family.

The family's wealth grew to be so substantial that (as Caskey explains) by 1268 they acted as bankers to the new king of Sicily, Charles I of Anjou. They became known as patrons of art and architecture in Ravello and during a twentyyear period commissioned the three great family works, namely the house, ciborium, and pulpit. During this time, they also lent heavily to the king and his son Charles of Salerno. This put the Rufolos in a precarious political position (as evidenced by Lorenzo and Matteo Rufolo's arrest in June 1283 on charges of corruption and fraud) as well as in a moral dilemma, for usury was not seen as the most honourable of occupations. With their arrests, the king succeeded in condemning not only Amalfitan wealth and political clout, but also the mercatantia in which it was rooted. As a result, the Amalfitan culture, and its various visual and public displays (as is the focus of Caskey's study) were also perceived as threatening for they, too, were rooted in mercatantia. Caskey next considers how this term manifested itself in domestic architecture by identifying the various types of housing in the region.

In reconstructing the general characteristics of a few of the housing types of the Amalfi region during the period in question, Caskey is able to draw several conclusions concerning the influence of mercatantia on domestic architecture. Examples are taken from the Rufolo House in Ravello, the D'Afflitto House in Pontone, and the Sasso House in Scala to demonstrate that these houses were designed to do more than provide shelter; they became symbols for artistic workmanship, family identification, and display. Essentially they became the visual products of the success of mercatantia. As Caskey tells us the "complex characters of the houses are inseparable from the act of mercatantia because the financial resources of the community were channeled into creating these lavish environments" (113). The forms of these houses also reflected the commercial experiences of the Amalfitans as evidenced by the presence of North African architectural influences. This influence was facilitated by a certain familiarity with Islamic art production, due to the presence of a Muslim community in the region. These public displays of wealth were not always favourably received, morally or legally. Although sumptuary legislations were not uncommon, the Angevin sumptuary 
legislation sought to curb these displays in the realm of private residential settings. In short, the domestic dwelling as Caskey notes "were expressions of wealth, cultural prestige, and difference, all fueled by mercatantia" (115).

From the private space we move to the public space with an analysis of public and private churches. In the third chapter, Caskey claims that "[ $\mathrm{t}] \mathrm{his}$ study establishes that private patronage shaped significant aspects of medieval religious experience in southwest Italy and calls into question the widely heralded novelty of lay patrons in canonical late medieval and early modern settings" (117). To invest in religious art and architecture was seemingly on of the few acceptable methods to demonstrate wealth by public display. Caskey analyzes three examples of residences paired with private churches: Sant'Eustachio in Pontone, San Michele Arcangelo in Pogerola and the Cathedral of Ravello commissioned by the Rufolo family. The latter is the most ambitious of the three and through an analysis of the art of mercatantia, Caskey explains how clear the ambitious nature actually was. While there was never any clear role for the wealthy laity, it is clear that, although it did not directly contribute to the arrests and consequent downfall of the Rufolo family, the grandness of the Cathedral of Ravello did contribute to the controversy surrounding wealth and public display. The fourth (and last) chapter outlines the decline of the art of mercatantia and the various pressures that led to that decline.

In what Caskey describes as a fundamental shift in culture, the Amalfitans moved away from their Mediterranean tradition, toward the modern ideals of the court, which contributed to the de-population of regions like Amalfi. Ultimately what Caskey is able to provide her reader, is a unique look at art history by analyzing the dominance of a force that is simultaneously economic, social and political in nature.

\section{ADRIANA GRIMALDI \\ University of Toronto}

Willard Bohn. The Other Futurism: Futurist Activity in Venice, Padua, and Verona. Toronto, Buffalo, and London: University of Toronto Press, 2004. Pp. $x, 215$. ISBN 0-8020-8816-3 (cloth). US\$ 50.

Willard Bohn's well-researched study is a welcome addition to the limited Englishlanguage materials available on Italian Futurism. Seeking to redress imbalances in Futurist scholarship, the volume highlights Venetia as an exemplary chronotope on which to enact a historiographic reconstruction. Bohn identifies three areas of investigation: (1) the Futurist activities in Venice, Padua, and Verona; (2) the Venetian practitioners of the movement; and (3) the second Futurist period (i.e., the interwar years) in the region. Bohn's detailed and descriptive approach provides an understanding both of Futurism's reception in Venetia and of Futurism's coherency in its regional manifestations.

Framed by a concise introduction and coda, the four informative chapters are augmented by fourteen pages of notes, an eight-page bibliography and a proper 